\title{
The Effect Of Digitalization On Culinary Msmes On Increasing Sales Turnover During Covid 19 Pandemic
}

\author{
Suryari Purnama ${ }^{1}$, Cicilia S. Bangun ${ }^{2}$, Arop Ria S. Panjaitan ${ }^{3}$, Sulthan Taqi Sampoerna ${ }^{4}$ \\ Faculty of Economics and Business Esa Unggul University, Indonesia ${ }^{1,3}$ \\ Faculty of Engineering Esa Unggul University, Indonesia ${ }^{2}$ \\ Faculty of Economics and Business, University of Raharja Indonesia ${ }^{4}$ \\ e-mail: suryari.purnama@esaunggul.ac.id ${ }^{1}$, cicilia.bangun@esaunggul.ac.id ${ }^{2}$, \\ ria.panjaitan@esaunggul.ac.id ${ }^{3}$, sulthan@raharja.info $^{4}$
}

Purnama, S. ., Bangun, C. S. ., Panjaitan, A. R. S., \& Sampoerna, S. T. . (2022). The Effect Of Digitalization On Culinary Msmes On Increasing Sales Turnover During Covid 19 Pandemic. Aptisi Transactions on Technopreneurship (ATT), 4(1), 59-68.

DOI: https://doi.org/10.34306/att.v4i1.228

\begin{abstract}
This study aims to determine the effect of digital marketing and the use of the marketplace for Culinary MSMEs on increasing sales turnover during the COVID-19 pandemic. The research population is Culinary MSMEs in DKI Jakarta whose number is unknown. Determination of the number of samples by Hair et.al (2014) which is a minimum of 50 culinary traders in Jakarta by sampling using the purposive sampling method, with the following criteria: Respondents are limited to small and micro entrepreneurs (UMK) Culinary, which sell heavy/main food, snacks (snacks) and various drinks, Culinary UMK actors who have used digital marketing as a promotional tool, Culinary UMK actors who have sold on marketplaces such as Gofood, Grabfood or Tokopedia. This research is a quantitative research that aims to see the effect of the data processing method used, namely Multiple Linear Regression Analysis. The results show: 1). There is an influence of digital marketing for Culinary MSMEs on increasing sales turnover during the covid 19 pandemic, 2). There is an effect of using marketplaces on increasing sales turnover of Culinary MSMEs, 3). There is an influence of digital marketing and the use of marketplaces on increasing Simultaneous sales turnover for Culinary SMEs. The novelty of this research is that it is found that the influence of the use of the marketplace is significant in increasing sales turnover, but specifically for Culinary MSMEs (Micro entrepreneurs) it turns out that the use of this marketplace reduces the sales turnover of these culinary Micro entrepreneurs.
\end{abstract}

Keywords: Culinary Smes, Digital Marketing, Use Of The Marketplace, Sales Turnover, Covid 19 Pandemic.

\section{Introduction}

The Covid pandemic that has hit the world since January 2020 has had an impact in all fields. Indonesia has also experienced economic difficulties due to the impact of this pandemic. According to the Organization for Economic Cooperation and Development (OECD) due to the Covid-19 pandemic, MSMEs have a significant impact. Their links to the tourism, transportation and raw material suppliers, all of which are affected, make MSME businesses very vulnerable [1]. 
Based on data from the Ministry of Cooperatives and MSMEs in 2018, around 99 percent of industries in Indonesia are supported by MSMEs. The number reached 64,194,057 units and employed 116,978,631 workers. Culinary MSMEs are the prima donna whose contribution is above 60 percent or around 40 million MSME actors. MSMEs as the backbone of the national economy are seriously affected not only in terms of production and income, but also in the reduction of the workforce due to this pandemic [2]. According to the Minister of Manpower, the largest number of companies and workers who were laid off were SMEs, especially in the tourism industry and its derivatives, such as hotels, restaurants and catering (horeca) (Kemenkop-UKM, 2018). This Culinary MSME also experienced a decrease in income by $92.47 \%$ [3], and had an impact on an increase in the number of poor people in September 2020 by 27.55 million people [4].

MSMEs occupy a strategic position in the economy in general. MSMEs are one of the strategic sectors in the national economy which can be seen from the absorption of labor [5]. Small businesses (MSMEs) are among the hardest hit by the COVID-19 crisis, many have temporarily closed their businesses, and furthermore face cash flow constraints [6]. According to the OECD (2020), MSMEs are at the center of the economic crisis due to the COVID-19 pandemic, even worse than the 2008 financial crisis. This crisis poses a serious risk that more than $50 \%$ of MSMEs will not survive the next few months.

As of April 17, 2020, as many as 37,000 MSME actors reported themselves to the Ministry of Cooperatives and MSMEs affected by the COVID-19 pandemic [7]. According to the data release, the difficulties experienced by MSMEs during the pandemic were divided into four problems. First, there is a decrease in sales turnover due to reduced community activities outside (56\%), second, capital difficulties due to declining sales levels $(22 \%)$. Third, there are product distribution barriers due to restrictions on the movement of people and goods $(15 \%)$. Fourth, the difficulty of raw materials (4\%). The impact of the pandemic on MSMEs is believed to be even greater, due to the high level of vulnerability and lack of resilience due to limited human resources, suppliers, and options for overhauling business models [8].

MSMEs are required to continue to communicate their products effectively to the public, which of course will lead to promotion costs. In connection with this pandemic, many MSMEs are having financial difficulties, so it is not easy for MSMEs to finance promotional activities. Social media has become a lifestyle for some people, so it can be used for promotion. In addition, sales turnover must be maintained so that production can continue, while the real market is almost closed due to the PSBB rules that prohibit the movement of goods and people. This is where the role of the marketplace as a virtual market is expected to replace the role of conventional markets.

The era of digitalization 4.0 has penetrated all fields, and is expected to be a solution in the midst of this pandemic. However, the current condition of MSMEs is vulnerable due to the low use of digitalization, only $3.97 \%$ of MSMEs are online, difficulties in accessing technology and lack of understanding of strategies to survive in business (OECD, 2020). So that MSMEs are encouraged to enter the online market, so they can penetrate the digital world with a wider market. Considering that internet users in Indonesia have penetrated $73.7 \%$ of the total population and have taken advantage of online shopping [9].

MSME actors are required to do product marketing intensively using digital marketing and social media to be able to reach consumers directly and reduce promotional costs. Digital Marketing helps companies or business actors in promoting, marketing products and services as well as being able to expand new markets that were previously closed or limited due to time, distance and ways of communicating. Digital marketing also develops when social media users increase quite sharply. Social media providers launch advertising services such as Facebook ads and Twitter ads. In this condition, technological disruption occurs. The glory of television and radio as the center of our attention is increasingly being shifted. Specifically for Indonesia, social media users have reached 170 million users, or equal to $61.8 \%$ of 
Indonesia's population [10]. The three most frequently used social media channels in Indonesia are YouTube, Facebook, and Instagram.

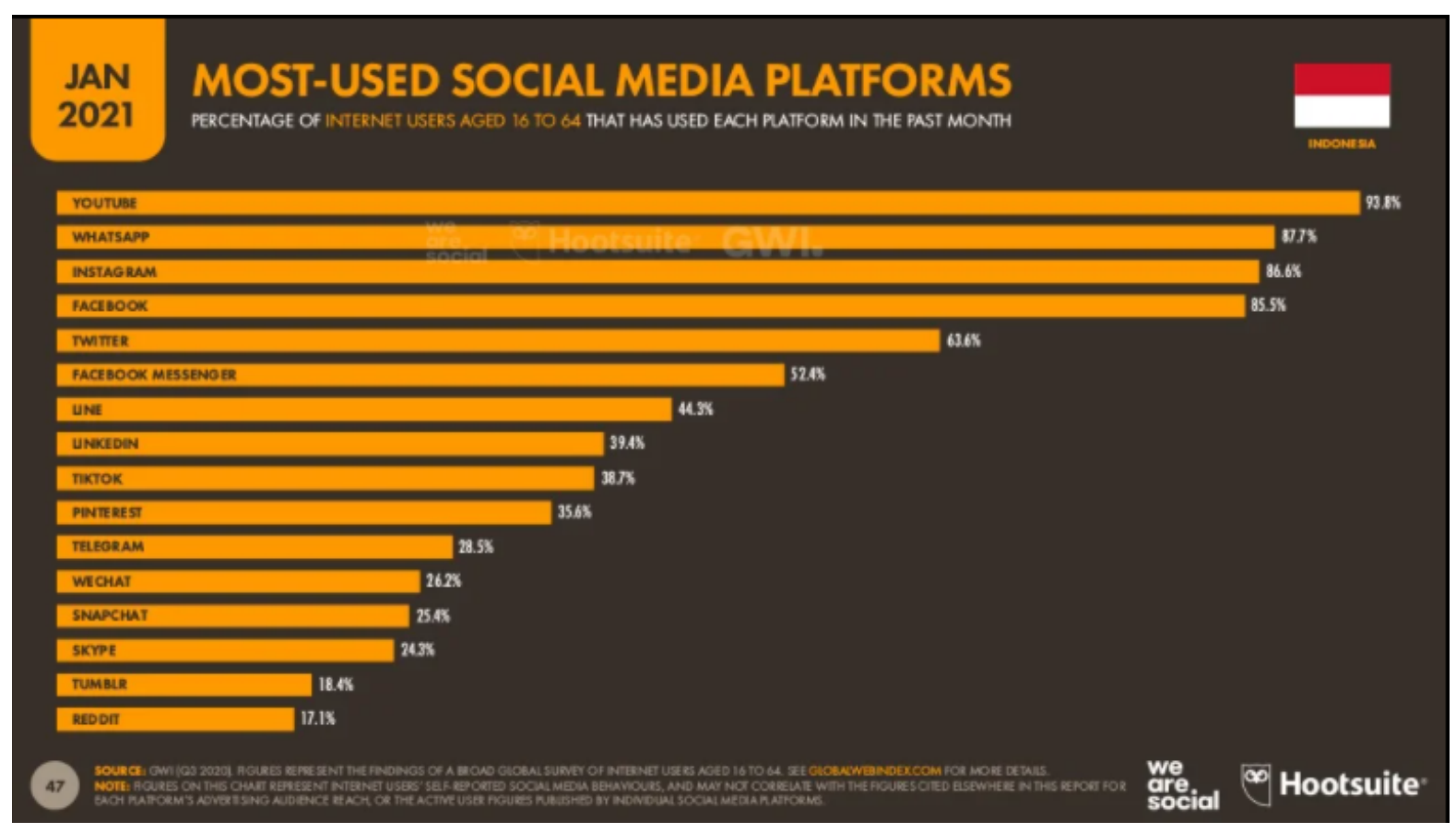

Source: https://datareportal.com/reports/digital-2021-indonesia

Figure 1. Social Media Most Often Used in Indonesia

To reduce the transmission of the Covid-19 virus, the government issued PP No. 21/2020 regarding PSBB, which contains restrictions on movement space direct buyers. To survive, business actors must take advantage of e-commerce. E-commerce is a system of selling, buying and marketing products by utilizing electronics [11]. Marketplace is one of the business concepts used by e-commerce. A marketplace is defined as a website or online application that facilitates the buying and selling process from various stores [12]. The concept of a marketplace is like a traditional market on the internet. Currently, there are many well-known marketplaces such as Tokopedia, Bukalapak, Grabfood and Gofood.

\section{Research Method}

This study used a descriptive research design, and used quantitative research methods. The quantitative research method used is a questionnaire technique with google form and hypothesis testing as a form to test the effect of each research variable which includes: the role of digital marketing, the use of the marketplace, and maintaining sales turnover.

In this study, the population is Culinary MSMEs in DKI Jakarta. Based on data from the Jakarta Provincial Government Integrated Data Portal in 2018, there were 1216 Culinary MSMEs in DKI Jakarta. The sample is a portion or part of a particular population that is of concern and has characteristics that are considered representative of the population [13]. The data processing method used is Multiple Regression Analysis. The data collection technique used in this research is a survey technique using questionnaires and interviews. Minimum number of samples to use regression analysis techniques is 15 to 20 times the number of variables used [14]. Given the limitations of time, cost, and resources, the researchers set the minimum number of respondents to be 50 respondents. Sampling by purposive sampling, has the following criteria: 
- Respondents are limited to small and micro entrepreneurs (MSMEs) Culinary, which sells heavy/main food, snacks (snacks) and various drinks

- Culinary MSME actors who have used digital marketing as a promotional tool

- Culinary MSME actors who have been selling in marketplaces such as Gofood, Grabfood or Tokopedia.

Measurements in the research for Digital Marketing variables adopted from Ryan and Jones [15]. Marketplace Utilization Variable adopted from E-Servqual theory from [16], sales turnover measurement adopted from [17]. In this study the data obtained using a questionnaire with the Likert scale method. Furthermore, the validity test was carried out on 30 respondents using confirmatory factor analysis where the results showed that all statement questionnaires on digital marketing, marketplace utilization and sales turnover had been declared valid, provided that the KMO and MSA anti-image correlation > 0.500 [18]. Likewise, the reliability test of Cronbach's alpha value $>0.6$ shows good reliability and the results of all variables are reliable with Cronbach's alpha $>0.6$ [19]. In this multiple linear regression analysis, the classical assumption tests calculated using the SPSS program include: (1) normality test (2) Multicollinearity test, the way to detect it is by looking at the VIF value, if the value is $<10$ then the data does not occur multicollinearity. (3) Autocorrelation test, the way to detect it is by using the Durbin Watson test. (4) Heteroscedasticity test, one way to detect it is to use the Breusch Pagan Test method [20].

\subsection{Literature Review of MSME}

MSMEs are an abbreviation of Micro, Small and Medium Enterprises (MSMEs). The government has established the definition of MSME and its criteria. This is stated in Law Number 20/2008 concerning Micro, Small and Medium Enterprises.

The criteria for micro, small and medium enterprises (MSMEs) are as follows:

1. The criteria for Micro Enterprises are businesses that have a net worth of at most Rp. 50 million excluding land and buildings for business premises. Have annual sales of at most Rp. 300 million.

2. The criteria for Small Business are businesses that have a net worth of more than Rp. 50 million up to a maximum of Rp. 500 million, excluding land and buildings where the business is located. Have annual sales of more than Rp. 300 million up to a maximum of Rp. 2.5 billion.

3. The criteria for Medium Enterprises are businesses that have a net worth of more than Rp. 500 million up to a maximum of Rp. 10 billion, excluding land and buildings for business premises. Have annual sales of more than Rp. 2.5 billion up to a maximum of Rp. 50 billion.

The characteristics of MSMEs are that businesses can move around, do not stay in one place, the types of goods sold can change at any time, there is no strict SOP that regulates, simple financial administration, sometimes personal finances and company finances are still combined, most of them do not have business legality, there is no strict and systematic system to regulate HR issues in business entities.

\section{- Digital Marketing}

Digital Marketing is a marketing activity including branding that uses various web-based media [21]. The definition of marketing or digital marketing is the use of digital technology to achieve marketing goals as well as efforts to develop or adapt the marketing concept itself, communicate on a global scale, and change the way companies do business with customers [21] [22] states that the presence of digital marketing is due to advances in technological developments with Web 2.0 coupled with mobile technology, everyone who has an internet network, can get accurate information just in the palm of their hand. Making the 
company 'easy' to be accessed by customers, this is the essence of digital marketing. This is what is meant by a true horizontal approach. When marketers and customers are in the same position, both can reach each other, customer satisfaction with service can be fulfilled, because customers must be served horizontally [23]. The principles of The Seven Laws, which is an acronym for DIGITAL, are: Differentiate products or services; simplify Ideas; Use creativity; Identify the position of the customer or buyer in digital media; Keep promises; Align between digital marketing strategy and organizational strategy; See what the market wants [24] era new wave, it is increasingly demanding marketers to think towards marketing with a low budget high impact. From here, many marketers then began to explore the world of social media to attract and retain their customers because the marketing media is profitable for companies with low budgets, but the impact is very high [25] found that the digital marketing strategy had an effect of up to $78 \%$ on the competitive advantage of MSMEs in marketing their products [26]. The use of the internet has changed most of the concepts of marketing which previously only relied on the marketing mix consisting of product, price, place and promotion, but the current development is an addition to the basis of marketing, namely the $4 \mathrm{C}$ approach consisting of customer, cost, convenience and communication [27]. Businesses must consider costs to maximize profits and use the internet to make consumers comfortable, because consumers can buy products only from home, and companies need to develop two-way communication in order to form good relationships with customers [28].

\section{- Marketplace}

Marketplace is a website or online application that facilitates the buying and selling process from various stores. Marketplaces have more or less the same concept as traditional markets. Marketplace owners are not responsible for the goods sold because their job is to provide a place for sellers who want to sell and help find customers and make transactions more simple and easy. The transaction is regulated by the marketplace, then after payment the seller will send the goods to the buyer. One of the reasons why the marketplace is famous is because of the ease and convenience of use. Many describe online marketplaces as department stores. In Indonesia, you can find various marketplaces, such as Tokopedia, Bukalapak, Blibli, JD.ID, Shopee, Elevenia and many more. This marketplace is very helpful for business actors to sell their products to various regions, regions and even to various other parts of the world where it is hoped that they will be able to increase the income of the business actors themselves.

According to Teten, digitalization is a solution to the problems faced by SMEs today. Therefore, a strong collaboration between the government and digital platforms such as GoFood and Gojek is needed to revive MSMEs in the food and beverage sector in Indonesia. The Covid-19 pandemic which gave birth to social distancing, physical distancing, Work From Home, Large-Scale Social Restrictions (PSBB) or whatever the term, according to Teten, made people shop online [29]

\section{- Sales Turnover}

Chaniago gives an opinion about sales turnover as the total amount of income obtained from the results of an item/service within a certain period of time [30]. Swastha gives the understanding that sales turnover is the accumulation of sales activities of a product [31], goods and services which are calculated as a whole over a certain period of time continuously or in an accounting process. In practice, sales activities are influenced by several factors as follows, namely the condition and ability of the seller, market conditions, capital, company organizational conditions and other factors, such as: advertising, demonstrations, campaigns, gift giving, which often affect sales [32]. According to Forsyth (1990) the factors that influence the decline in sales include internal factors and external factors.

\subsection{Hypotheses}

$\mathrm{H} 1$ : It is suspected that there is an influence of digital marketing on increasing sales turnover of Culinary MSMEs 
H2: Allegedly there is an effect of utilization on increasing sales turnover of Culinary MSMEs

H3: Allegedly there is an influence of digital marketing and the simultaneous use of marketplaces on increasing sales turnover of Culinary MSMEs

\section{Findings}

This research focuses on culinary MSME traders in DKI Jakarta. Data collection was carried out by visiting culinary traders at the outlets, obtaining 156 respondents who were willing to fill out the google form. Based on the results of the study, it can be seen that all hypotheses $\mathrm{HO}$ are rejected and $\mathrm{Ha}$ are accepted, meaning that there is a significant influence between digital marketing variables and the use of marketplaces on increasing sales turnover. The results of data processing with SPSS found the following line equation: $=3.865+0.244$ $\mathrm{X} 1-0.168 \mathrm{X} 2$. From the results of the regression equation, it can be seen that the digital marketing variable has a positive influence so that the addition of 1 unit in digital marketing will provide an increase in sales turnover of 0.244 . The results of this study are in accordance with previous research from Wardhana, that the use of digital marketing helps in informing and interacting directly with consumers. The use of digital marketing expands their market share, increases awareness for consumers because MSME actors routinely update product information every day and increase sales because several MSEs also collaborate with several marketplaces such as Shopee and Tokopedia, whose food and beverage categories collaborate with the Go-Food application [33] [34] [35].

For an increase of one unit in the variable use of the marketplace, the value of sales turnover is reduced by 0.168 . This can be explained by looking at the demographics of the respondents. Based on data from the demographics of respondents, it can be seen that most of the respondents aged $18-28$ years are young $(96 \%)$, then female $(62 \%)$, and have used the marketplace $<6-12$ months (56\%), culinary SMEs in the form of heavy food. with a very economical price $<10$ thousand -20 thousand $(60 \%)$ so that it can be classified as a Micro Business trader. From these demographics, it can be seen that traders have not been able to utilize the marketplace as optimally as possible due to limited mastery of information technology. They still have not mastered the system that applies in the marketplace [36] [37].

The results of this study, which became the novelty of this research, showed that for micro culinary entrepreneurs, the use of the marketplace did not increase their sales turnover. For example, in GoFood, there is a rating, or a rating made based on consumer ratings. The higher the rating of a culinary trader, the greater the chance that they will be chosen by consumers. So far they are used to serving customers who come to their place. Although consumers are waiting for their orders to be processed, consumers can see how their food is cooked, it becomes entertainment in itself [38]. Consumers will also wait more patiently, because they have already provided time to buy food outside the home. However, this is different from consumers who wait in their respective homes. They can't see the processing of food, and they can't predict how long it will take to cook, not to mention that food delivery takes time. So waiting for them becomes a tedious thing. When they feel dissatisfied, they easily give a low rating or rating, which of course will have a bad impact on the culinary traders [39]. These culinary traders do not know that the speed of cooking food and the speed of delivery have an effect on consumer satisfaction. Likewise, the taste of good food, presentation in good packaging, it becomes one of the consumer's assessments. If consumers are satisfied, they will not hesitate to give a high rating. The digital marketing variable has a positive influence but with a small value addition coefficient of 0.244 . It is understandable that knowledge is needed to utilize and use social media. Creating promotions through social media requires special skills and takes time if you want to create promotional content that consumers can digest and understand [40] [41]. This ability is what they do not yet have so that promotional activities or socialization about their products cannot be carried out optimally through digital marketing [42]. This happens because of the limitations of culinary MSME 
traders such as insufficient number of human resources, limited capital, low education level, limited insight and very low ability to adapt to technological advances.

\subsection{Research Implementation}

- Theory Implications

Based on the results of this study, the theoretical implications that can be given are that digital marketing variables and the use of the marketplace have an effect on increasing sales turnover, but the use of the marketplace has actually decreased sales turnover. This can happen due to demographic factors of age, gender, education, less than a year of use of the marketplace, and lack of mastery of technology. This pandemic situation is forcing culinary traders to survive by selling using digital technology. Apart from that, they are not ready for the pandemic situation that makes them lose consumers due to the PSBB regulations from the government, and at the same time they are also forced to be able to adapt to digital technology.

\section{- Managerial Implications}

Based on the findings of the research, intervention from the government or related agencies and even universities is needed to foster and also assist these culinary SMEs. They need training or workshops on a regular basis and if possible free of charge, so that many Culinary MSME actors can take part in these activities.

\section{Conclusion}

Based on the problems and objectives proposed in this study, the following conclusions were drawn: 1) There is an effect of digital marketing for Culinary MSMEs on increasing sales turnover during the covid 19 pandemic. 2) There is an effect of using marketplaces on increasing sales turnover for Culinary MSMEs, 3) There is an influence of digital marketing and the use of the marketplace on increasing sales turnover simultaneously for Culinary MSMEs.

\section{References}

[1] Ali, Hasan (2013), "Marketing and Selected Cases". Yogyakarta: Center for Academic Publishing Service.

[2] Andriatie, Noor Hastuti. (2020). "Utilization of E-Commerce in an Effort to Increase Sales of Ornamental Flowers for the Cyclop Sustainable Community in Jayapura". The Community Engagement Journal, Vol 3 No 2, June 2020.

[3] Artaya, I Putu and Tubagus Purwotusmiadi. (2019). "Marketplace Effectiveness in Increasing the Concentration of Marketing and Product Sales for MSMEs in East Java". https://www.researchgate.net/publication.

[4] Awali, H. (2020). Urgensi Pemanfaatan E-Marketing Pada Keberlangsungan Umkm Di Kota Pekalongan Di Tengah Dampak Covid-19. BALANCA: Jurnal Ekonomi dan Bisnis Islam, 2(1), 1-14.

[5] Baker, T. H., \& Judge, K. (2020). How to help small businesses survive COVID-19. Columbia Law and Economics Working Paper, (620).

[6] BPS. (2020). Retrieved from https://www.bps.go.id/pressrelease/2021/02/15/1851/persentase-penresident-miskin-sept ember-2020-naik-menjadi-10-19-persen.html

[7] Dwijayanto, Andi (2020). As a solution for SMEs during the Covid-19 pandemic, Coordinating Minister Teten appreciates GoFood. Retrieved from https://industri.kontan.co.id/news/jadi-solution-UMKM-saat-pandemi-covid-19-menkop-tet en-apresiasi-gofood. 
[8] Dwijayanti, A., \& Pramesti, P. (2021). Pemanfaatan Strategi Pemasaran Digital menggunakan E-Commerce dalam mempertahankan Bisnis UMKM Pempek4Beradek di masa Pandemi Covid-19. Ikra-Ith Abdimas, 4(2), 68-73.

[9] Affandi, A., Sarwani, A. S., Erlangga, H., Siagian, A. O., Purwanto, A., Effendy, A. A., \& Juhaeri, G. (2020). Optimization of MSMEs empowerment in facing competition in the global market during the COVID-19 pandemic time. Systematic Reviews in Pharmacy, 11(11), 1506-1515.

[10] Djatmiko, A., \& Pudyastiwi, E. (2020). Obstacles And Challenges Of Indonesia's Micro, Small And Medium Enterprises (Umkm) In Facing The Covid-19 Pandemic. Jurnal Pendidikan Kewarganegaraan Undiksha, 8(3), 117-123.

[11] Kemp, Simon. (2021). Digital 2021: INDONESIA. Retrieved from https://datareportal.com/reports/digital-2021-indonesia

[12] Wibisono, I. P. (2019). Making Digital Marketing Strategies in the Hotel Industry: Case Study of Implementation of New Wave Marketing on Budget Hotel. Indonesian Journal Of Business And Economics, 2(2).

[13] Armstrong, G., Adam, S., Denize, S., \& Kotler, P. (2014). Principles of marketing. Pearson Australia.

[14] Malhotra, N. (2014). Basic Marketing Research. England.

[15] Nassiuma, B., Masinde, J., Chebii, P., \& Sergon, D. (2021). Enterprisers Profile Group Differentials and Firm Sales Turnover in Western Kenya. Journal of Small Business and Entrepreneurship, 9(2), 23-33.

[16] Nurfitria, N., \& Hidayati, R. (2011). Analisis Perbedaan Omzet Penjualan Berdasarkan Jenis Hajatan dan Waktu (Studi Pada Catering Sonokembang Semarang) (Doctoral dissertation, Universitas Diponegoro).

[17] Syihabudin, S., \& Gumelar, R. G. (2019). Digital Marketing Communication Development On Micro, Small And Medium Enterprises (Msme) In Era 4.0 Based On Sharia Economic (Case Study Msme Domas Village, Pontang District).

[18] Kaberia, S. K., \& Muathe, S. (2021). Effect of Covid-19 pandemic on performance of women owned micro, small and medium Enterprises in Kenya. Int'I J. Soc. Sci. Stud., 9, 7.

[19] Munsch, A. (2021). Millennial and generation $Z$ digital marketing communication and advertising effectiveness: A qualitative exploration. Journal of Global Scholars of Marketing Science, 31(1), 10-29.

[20] Nuraida, W., Hikmaida, A. A., Aisyah, T. P., \& Vernanda, S. Z. (2021). The Government's Efforts to Maintain Economic Stability During The COVID-19 Pandemic. IN-PROLEGURIT, 1(1), 463-479.

[21] Weygandt, J. (2011). Research Methods for Business. Jakarta: Salemba Empat.

[22] Arie, H. A., \& Fikry, A. M. (2021). Development of synergistic between digitalization MSMEs and digital society in Indonesia. HO CHI MINH CITY OPEN UNIVERSITY JOURNAL OF SCIENCE-ECONOMICS AND BUSINESS ADMINISTRATION, 11(2), 18-30.

[23] Dora, Y. M., NurAmalina, H., \& AuliaRahmi, F. (2020). The Role Of Training, Motivation And Facilities To Improve The Capability Of Smes In Using Digital Marketing. PalArch's Journal of Archaeology of Egypt/Egyptology, 17(10), 3942-3951.

[24] Shafi, M., Liu, J., \& Ren, W. (2020). Impact of COVID-19 pandemic on micro, small, and medium-sized Enterprises operating in Pakistan. Research in Globalization, 2, 100018. 
[25] Kodrat, K. F., Supiyandi, S., \& Mesran, M. (2018). Application of multi-objective optimization on the basis of ratio analysis (MOORA) in strategic location marketing. Int $\mathrm{J}$ Sci Res Sci Technol, 4(2), 681-686.

[26] Wahyuni, N., \& Gunawan, A. (2018). Pengenalan Dan Pemanfaatan Marketplace E-Commerce Untuk Pelaku Ukm Wilayah Cilegon. Jurnal Pengabdian Dinamika, 5(1).

[27] Wardhana, A. (2015, April). Strategi digital marketing dan Implikasinya pada Keunggulan Bersaing UKM di Indonesia. In Seminar Nasional Keuangan Dan Bisnis IV (pp. 327-337).

[28] Wulandari, O. A. D., Ujiani, U., \& Putri, N. R. (2020). Analisis Pemanfaatan Marketplace Dalam Meningkatkan Pendapatan Bagi Penjualan Produk Umkm Di Purbalingga. Jurnal Ekonomi Manajemen, 6(2), 96-101.

[29] Ribaya, B., Niemann, D., Makarewicz, J., Clevenson, H., McKenzie, C., Nguyen, C., \& Blake, D. F. (2009, December). Micro-column Scanning Electron Microscope and x-ray Spectrometer (MSEMS) for planetary exploration. In AGU Fall Meeting Abstracts (Vol. 2009, pp. P43A-1421).

[30] Akbar, B. A. P., Magfuri, I. M., \& Apriliasari, D. (2021). Pelatihan Kewirausahaan di Kampung Literasi Berdaya Saing Menuju Revolusi Industri 4.0. ADI Pengabdian Kepada Masyarakat, 2(1), 36-42.

[31] Fitra, A. B., Suharko, A., Albar, F. M., \& Apriliasari, D. (2022). Examination Of Customer Interest In The Use Of The Mandiri Syariah Mobile Application At PT. Bank Syariah Mandiri Bekasi Branch Office. IAIC Transactions on Sustainable Digital Innovation (ITSDI), 3(2), 110-125.

[32] Fauziah, Z., Latifah, H., Omar, X., Khoirunisa, A., \& Millah, S. (2020). Application of Blockchain Technology in Smart Contracts: A Systematic Literature Review. Aptisi Transactions on Technopreneurship (ATT), 2(2), 160-166.

[33] Agustin, F., Aini, Q., Khoirunisa, A., \& Nabila, E. A. (2020). Utilization of Blockchain Technology for Management E-Certificate Open Journal System. Aptisi Transactions on Management (ATM), 4(2), 133-138.

[34] Putri, S. E. (2021). Enhancing Social Media Usage on Business Performance: MSEMs During The COVID-19 Pandemic in Indonesia. International Journal of Islamic and Social Sciences (ISOS), 1(2), 55-63.

[35] Cortina, J. M., Chen, G., \& Dunlap, W. P. (2001). Testing interaction effects in LISREL: Examination and illustration of available procedures. Organizational research methods, 4(4), 324-360.

[36] Kurniawati, E., Siddiq, A., \& Huda, I. (2020). E-commerce opportunities in the 4.0 era innovative entrepreneurship management development. Polish Journal of Management Studies, 21.

[37] Gajda, D., Guihenneuc-Jouyaux, C., Rousseau, J., Mengersen, K., \& Nur, D. (2010). Use in practice of importance sampling for repeated MCMC for Poisson models. Electronic Journal of Statistics, 4, 361-383.

[38] Stanley-Marbell, P. (2006). Implementation of a distributed full-system simulation framework as a filesystem server. In Proceedings of the First International Workshop on Plan (Vol. 9).

[39] Cambron, C., Hopkins, P., Burningham, C., Lam, C., Cinciripini, P., \& Wetter, D. W. (2020). Socioeconomic status, mindfulness, and momentary associations between stress and smoking lapse during a quit attempt. Drug and alcohol dependence, 209, 107840.

[40] Ekowanti, M. R. L., \& Ambarwati, A. (2019, March). Collaborative Governance in MSMEs Development (Case Study: Collaboration Model of Surabaya Local Government, Private, and MSMEs Association in MSMEs Development at Coastal Area of Surabaya). In ICEMSS 2018: Proceedings of the 1st International Conference on Emerging Media, and 
Social Science, ICEMSS 2018, 7-8 December 2018, Banyuwangi, Indonesia (p. 255). European Alliance for Innovation.

[41] Heikal, J., Rialialie, V., Rivelino, D., \& Supriyono, I. A. (2022). Hybrid Model Of Structural Equation Modeling Pls And Rfm (Recency, Frequency And Monetary) Model To Improve Bank Average Balance. Aptisi Transactions on Technopreneurship (ATT), 4(1), 1-8

[42] Setyahuni, S. W., \& Triyani, A. (2022). Factors Affecting Corporate's Coping Strategy Choice During The Covid-19 Outbreak: Case of Indonesia. Riset Akuntansi dan Keuangan Indonesia, 6(3), 334-349. 